\title{
The Effect of Forest Fragment Characteristics on Abundance of Colobus vellerosus in the Forest-Savanna Transition Zone of Ghana
}

\author{
Bright O. Kankam ${ }^{a}$ Pascale Sicotte ${ }^{b}$ \\ ${ }^{a}$ Forestry Research Institute of Ghana, KNUST, Kumasi, Ghana; ${ }^{b}$ Department of \\ Anthropology, University of Calgary, Calgary, Alta., Canada
}

\author{
Key Words \\ Colobus vellerosus $\cdot$ Abundance $\cdot$ Fragmented habitat $\cdot$ Forest quality
}

\begin{abstract}
We explore the factors influencing the abundance of Colobus vellerosus in 11 forest fragments [Boabeng-Fiema Monkey Sanctuary and 9 surrounding forest fragments (range: 3.2-190 ha)] in the forest-savanna transition zone of Ghana. We used a 'complete' count for the colobus census in the fragments. We determined the fragment sizes using geographic information system methods and assessed forest fragment quality (tree species richness). Colobus individuals were absent from 4 forest fragments but present in 7 (densities of $0.13 /$ ha-1.63/ha). We modelled colobus density using Poisson regression and selected models based on corrected Akaike information criterion model weights. Fragment size and tree species richness in the fragments were positively associated with colobus density, whereas isolation distance of the forest fragments (range: 20-5,632 m) was negatively associated with colobus density. Our analysis suggests that the isolation distance between the fragments and Boabeng does impede colobus movement. As the colobus populations in Boabeng and Fiema increase, some of the unoccupied fragments may become more attractive to dispersing monkeys. Management measures that aim at increasing tree species richness within fragments, while maintaining some large trees between fragments, might help to increase the occupancy of some of the fragments that currently have no permanent colobus groups.
\end{abstract}

Copyright $\odot 2013$ S. Karger AG, Basel

\section{Introduction}

Folivorous primates such as Colobus spp. can survive on low-quality diets, a strategy believed to sustain their ability to survive in forest fragments (C. guereza [Onderdonk and Chapman, 2000]; C. vellerosus [Wong and Sicotte, 2006; Wong et al., 2006]).

\begin{tabular}{l}
\hline KARGER \\
$\begin{array}{l}\text { E-Mail karger@karger.com } \\
\text { www.karger.com/fpr }\end{array}$
\end{tabular}

\author{
Bright O. Kankam \\ Forestry Research Institute of Ghana \\ PO Box 63, KNUST \\ Kumasi (Ghana) \\ E-Mail bokankam@yahoo.com
}


For populations living in habitats composed of naturally or anthropogenically fragmented forests, the characteristics of the fragments influence animal movements between, and long-term use of, the fragments. Distance between fragments, fragment size, as well as various measures of habitat quality (e.g. density of trees [Chapman and Chapman, 1999; Mbora and Meikle, 2004]; tree diversity [Medley, 1993; Chapman and Chapman, 1999]; forest cover [Arroyo-Rodriguez et al., 2008]) are among the characteristics that have been identified as important influences on the presence and abundance of primates in these habitats [Medley, 1993; Chapman and Chapman, 1999; Chapman et al., 2003; Rodriguez-Toledo et al., 2003; Mbora and Meikle, 2004; Anderson et al., 2007; Arroyo-Rodríguez et al., 2008; Arroyo-Rodríguez and Dias, 2010; Boyle and Smith, 2010]. It is becoming apparent, however, that primate populations show variable responses to fragmented habitats, depending on their specific requirements and on local ecological conditions [Anderson et al., 2007; Boyle and Smith, 2010].

This research aims to explore the factors that influence the abundance of a species of colobus, C. vellerosus, in a naturally fragmented yet anthropogenically modified habitat in the forest-savanna transition zone in central Ghana. The forest-savanna transition zone in West Africa is a narrow overlap of the vegetation between the tropical humid forest to the south and the Guinea savanna to the north [Swaine, 1992]. The vegetation of the transition zone is a mosaic of forest tree species, fireresistant savanna tree species, and grassy undergrowth [Hopkins, 1974]. Most forest trees in this zone are 10-12 $\mathrm{m}$ in height, with a uniform canopy; however, a few deciduous and evergreen tree species can grow much bigger under favourable conditions [Swaine, 1992]. Factors such as climatic conditions [Migeod, 1914; Swaine et al., 1976; Salzmann, 2000], geology and topography [Allison, 1962; Asare, 1962; Swaine et al., 1976] and bush fires [Swaine, 1992] have been suggested to be key in explaining the nature of forest-savanna transition vegetation.

The history of the creation of the Boabeng-Fiema Monkey Sanctuary (BFMS) and subsequent surveys of the surrounding fragments suggest that the colobus monkeys in the area were found only in the present-day Sanctuary [Fargey, 1991; Kankam, 1997; Kankam et al., 2010]; but later moved to the surrounding forest fragments [Kankam, 1997; Wong and Sicotte, 2006]. Interviews with members of the communities also suggest that monkeys have gradually dispersed from Boabeng towards the other fragments since the 1970s [Kankam, 1997; unpubl. data]. Our goal in conducting this research was to enhance our knowledge of the response of $C$. vellerosus to naturally fragmented habitats that are under anthropogenic influence and to underline the importance of managing a network of small forest fragments to maintain viable populations of primates [Laurance, 1994; Turner and Corlett, 1996; Boyle and Smith, 2010]. Given that C. vellerosus is an arboreal forest primate, we expected $C$. vellerosus densities to vary positively with forest fragment size and habitat quality, and to vary negatively with isolation distance from the main forest (Boabeng) that has closed forest [Kankam et al., 2010].

\section{Materials and Methods}

Study Site

The BFMS is composed of 2 forest fragments, and the 9 surrounding fragments are located in the Nkoranza North District of the Brong-Ahafo region in Ghana (fig. 1). These forest fragments are each associated with a village. The surrounding fragments lie within a 10-km radius of the BFMS

Effect of Forest Fragment Characteristics on Abundance of C. vellerosus
Folia Primatol 2013;84:74-86 DOI: $10.1159 / 000348307$ 


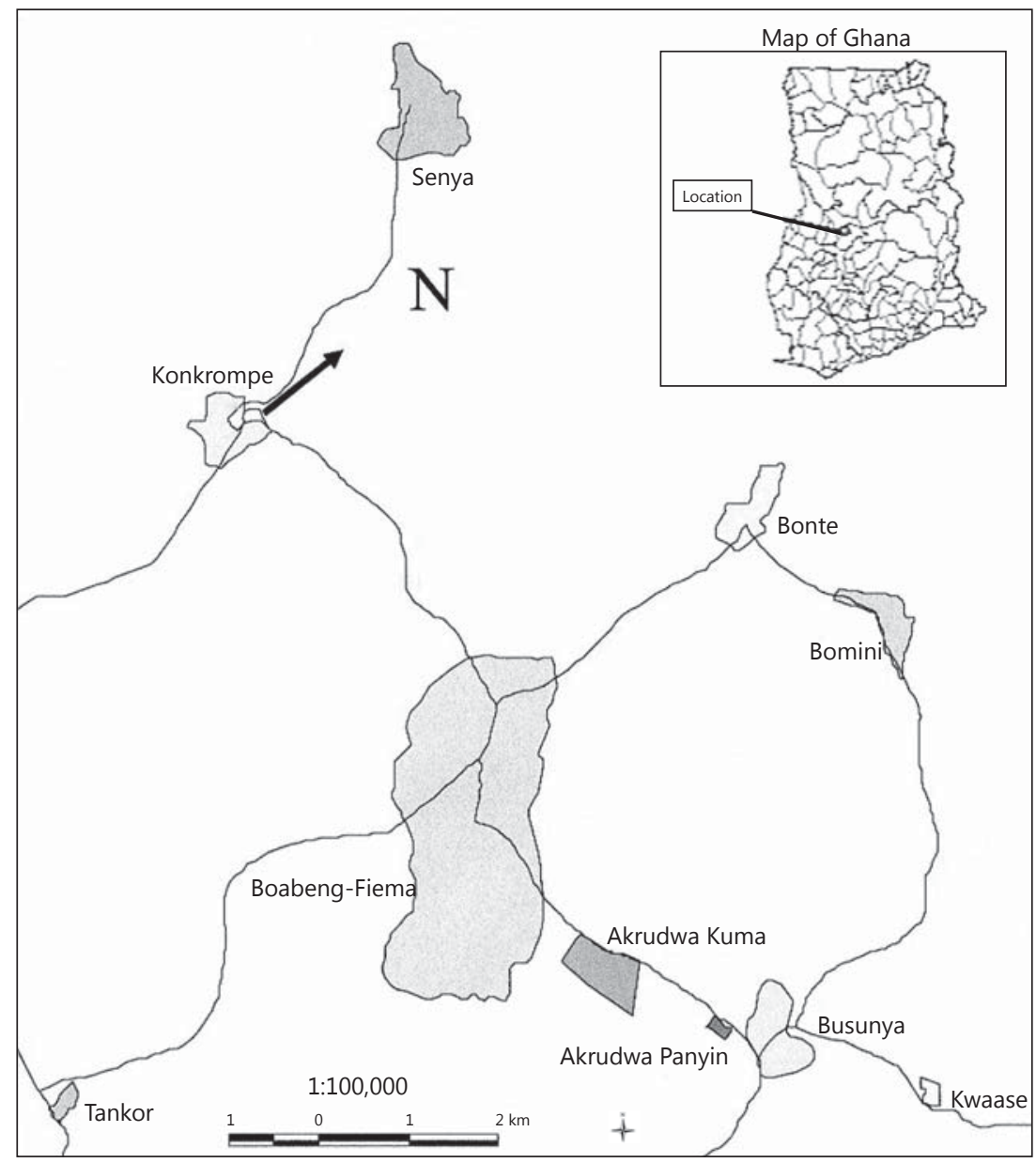

Fig. 1. BFMS and surrounding fragments.

(fig. 1). This complex of forest fragments is $50 \mathrm{~km}$ away from other large forest blocks [Beier et al., 2002]. The land around the BFMS and the surrounding fragments (the forest 'matrix') is used mainly for agricultural purposes (primarily maize, yam, cassava, cocoyam, groundnut and plantain, with cashew as the major cash crop). Some fragments are directly adjacent to, or located around, a village.

The vegetation type falls within the northern forest-savanna transition zone of Ghana $\left(7^{\circ} 41^{\prime} \mathrm{N}, 1^{\circ} 39^{\prime} \mathrm{W}\right)$, which is characterized by forest and savanna woodland vegetation [Swaine et al., 1976; Hall and Swaine, 1981]. Mean annual precipitation in the area was 1,102.1 mm from 2000 to 2006 (Ghana Meteorological Agency data). The forest fragments of Boabeng and Fiema shelter 2 diurnal species of primates (C. vellerosus and Cercopithecus campbelli lowei) [Fargey, 1991; Kankam, 1997] and 1 nocturnal primate (Galago demidoffi) [S. Bearder, unpubl. report]. C. vellerosus has been reported in some of the other fragments [Kankam, 1997; Wong and Sicotte, 2006].

Study Species

C. vellerosus is endemic to the Upper Guinean Forest of West Africa [Groves, 2001]. The species lives in primary, secondary and riverine/swamp forests, as well as in fragmented forested 
habitats [Kankam, 1997; Wong and Sicotte, 2006; Saj and Sicotte, 2013]. The species is arboreal but does travel on the ground [Booth, 1956; Jeffrey, 1975] and moves between forest fragments [Wong and Sicotte, 2006] by using agricultural areas when a few large trees remain [B.O. Kankam, pers. obs.]. C. vellerosus is primarily folivorous and includes small amounts of fruits and seeds in its diet [Saj and Sicotte, 2007]. The group size of C. vellerosus in the BFMS varies from 3 to 38 individuals (mean: 10.3-15.1 individuals) [Saj et al., 2005; Wong and Sicotte, 2006]. The population at the BFMS is increasing [Wong and Sicotte, 2006; Kankam et al., 2010] and is possibly the only growing population of C. vellerosus in West Africa [Saj and Sicotte, 2013]. It is listed as vulnerable in the International Union for Conservation of Nature's Red List [IUCN, 2010].

C. vellerosus Population Census

We conducted a census of the C. vellerosus population in the 11 fragments using the complete (or total) count method [Jarman et al., 1996; Ross and Reeve, 2003]. A complete count can be reasonably attained under certain conditions: (1) the population is closed (i.e. no animals are moving in or out of the constellation of fragments from other forested areas), which is the case here due to the location of these fragments away from larger forest blocks and due to the fact that the census took place over a short period ( 5 days, see below); (2) all the groups can be identified by location and often by the presence of specific individuals, and (3) visibility is good [Ross and Reeve, 2003]. In the case of this study, during the precensus period, existing trails, new trails, footpaths and roads were used to gain access to various parts of the forests. Most fragments were rather small, and most of them contained few groups. The fragments were all associated with a village. Villagers use their fragments for a range of activities, e.g. grazing of domestic animals, extraction of forest products and latrines. As a result, most groups were relatively accustomed to human presence and activity. In the precensus period, the groups were identified and their general location assessed by one of the authors (B.O.K.) and his team of research assistants, which included people residing in each of the villages associated with a forest fragment.

At the beginning of the census, 39 trained research assistants were simultaneously at work in the 11 fragments surveyed. Research assistants were given the task of locating a given group in the morning of each census day (or in the case of a fragment with no colobus groups, the task of walking the fragment to confirm the absence of a group). Five census days took place between August 29 and September 2, 2007. The censuses were carried out at the same time (from 10.00 to $15.00 \mathrm{~h}$ ) to avoid counting individuals or groups that might have been moving between fragments during the census period. Research assistants counted the number of individuals in the group to which they were assigned, assessed age-sex class composition every hour during the $5 \mathrm{~h}$ that they stayed with the group, and noted whether the count was a 'good' count or not. A 'good' count was characterized by the fact that the group either crossed an open area during counting, or was in a tree with good visibility [Baker et al., 2009]. Research assistants were rotated between groups and between fragments on a daily basis to get distinct counts and minimize biases in the counts. As a result, the accuracy of counts did not necessarily improve with time during the census.

Although the aim of the census method we used was theoretically to count all individuals in the population, we know that census group counts underestimate 'real' group counts obtained on research groups as a result of daily monitoring and individual recognition. Group size is underestimated between 10 and 33\% with the greatest error occurring with the largest group [Wong and Sicotte, 2006]. This is probably somewhat offset in the present census by the fact that research assistants spent several hours with specific groups to obtain a good count. Finally, our census team did not record the presence of all-male bands in any of the fragments, despite the fact that they are known to occur. This had been the case in prior censuses conducted at the site as well [Saj et al., 2005; Wong and Sicotte, 2006]. This suggests that all-male bands are short-lived [Teichroeb et al., 2011].

The values used for the analysis are the maximum values recorded during the 'good' group counts during the 5 days of the census. In the case of the large fragments with several groups of colobus, it happened that no good counts were made in a given day for at least one of the groups. These days are not used in our analysis ( $\mathrm{n}=3$ for Boabeng and $\mathrm{n}=2$ for Fiema). All other fragments use the 5 days of the census.

Effect of Forest Fragment Characteristics on Abundance of C. vellerosus
Folia Primatol 2013;84:74-86 77 DOI: $10.1159 / 000348307$ 
Fragment Size and Habitat Quality

B.O.K. mapped the boundaries of the forest fragments on foot using a Global Positioning System (GPS; Garmin 60SC). The GPS waypoints were read every $10-15 \mathrm{~m}$ on straight boundary lines, and every 3-5 $\mathrm{m}$ where there were curves [Kankam et al., 2010]. We used Garmin MapSource software version 2.00 to download the GPS waypoints before importing the data into GeograArcView GIS 3.3 for analysis at the Centre for Remote Sensing and Geographic Information Services, University of Ghana at Legon. We calculated the isolation distance in metres as the closest point from the likely source (Boabeng) to each fragment and fragment size (measured in hectares) by using a Geographic Information System (GIS) database (ArcView 3.3).

For the purpose of this study, a forest is described as an area of more than 0.5 ha, having an overstorey canopy that covers not less than $10 \%$ of the area [Dudley and Phillips, 2006]. A closed forest is characterized by a high percentage of tree overstorey (40-70\% canopy cover) and undergrowth with a scattered grass layer [Kufeld et al., 1988; Baytas and Rezvani, 2000; Achard et al. 2002]. An open forest has continual forest with tree crown cover between 10 and $40 \%$ with a continuous grass layer undergrowth [Kufeld et al., 1988; IUCN, 1996; Baytas and Rezvani, 2000; Achard et al., 2002]. Savanna woodland habitat includes woodland and grassland, and is characterized by woody vegetation with short trees and shrub that has canopy cover greater than $10 \%$ [Dudley and Phillips, 2006]. The savanna woodland habitat is characterized by Chromolaena odorata weed, grasses and scattered forest trees [Afikorah-Danquah, 1997]. Forest on wetlands or forest along rivers and streams with varying canopy cover were referred to as riverine forest [Mitsch and Gosselink, 2000].

The stratified random sampling method [Scott, 1998; Barbour et al., 1999] was used to assess forest structure and composition to ensure that all vegetation types (see above) were surveyed in each fragment where they were present. Each forest type was classified according to its dominant vegetation types and structural attributes. Ninety-four $50 \times 50 \mathrm{~m}$ vegetation plots were placed at random (at least $20 \mathrm{~m}$ from the edge) in the 11 fragments in 2007. At least 2 plots were placed in each fragment and 1 or more plots were placed in all forest types if available in fragments and if the size of the forest type within a fragment was $>0.25$ ha. The plot numbers were adjusted to survey at least $5 \%$ (range: $5-16 \%$ ) of each fragment. More plots were laid in the larger fragments, but the percent plot cover was higher in smaller fragments. Each vegetation plot $(50 \times$ $50 \mathrm{~m})$ was divided into $25(10 \times 10 \mathrm{~m})$ subplots to study woody trees with $\geq 10 \mathrm{~cm}$ diameter at breast height. The diameter at breast height of trees was measured at $1.3 \mathrm{~m}$ above the ground; however, in cases where buttresses were present at breast height, the readings were taken above the tree buttress. When a tree stem divided into 2 below $1.3 \mathrm{~m}$, it was treated as 2 stems; however, stems that divided into 2 or more above $1.3 \mathrm{~m}$ were treated as a single stem and branches with $\geq 10 \mathrm{~cm}$ diameter at breast height were measured [Condit et al., 1998]. We used a clinometer to measure the height of the trees.

Tree species richness was calculated as the number of tree species with $\geq 10 \mathrm{~cm}$ diameter at breast height per fragment. Tree identification was made on the basis of Abu-Juam et al. [1996], Hawthorne and Gyakari [2006] and Hawthorne and Jongkind [2006]. We collected leaf samples as well as fruits, seeds, flowers and bark layer of trees when available for tree species which could not be identified on-site and sent them to the herbarium of the Botany Department at the University of Ghana, Legon for identification. All leaves were field pressed before being sent to the herbarium.

\section{Data Analyses}

We used Poisson regression analyses to investigate whether there was an association between colobus density and the 3 predictor variables (fragment size, isolation distance and tree species richness). Using an information-theoretic approach and maximum likelihood estimation techniques, the weight of evidence supporting each of the 7 possible models involving the 3 predictor variables (in addition to an intercept-only model) was calculated. Because of the small sample size, we then modelled the data based on the small sample corrected Akaike information criterion. We compared the competing models and their relative support to determine which model was best supported by the weight of evidence. The 8 candidate models were ranked based on their relative support in explaining colobus density in the fragments. In addition, the 3 vari- 
Table 1. 2007 census of C. vellerosus in BFMS and surrounding fragments

\begin{tabular}{|c|c|c|c|c|c|}
\hline \multirow[t]{2}{*}{ Community } & \multicolumn{3}{|c|}{ Age-sex composition } & \multirow{2}{*}{$\begin{array}{l}\text { Monkeys } \\
\mathrm{n}\end{array}$} & \multirow{2}{*}{$\begin{array}{l}\text { Groups } \\
\mathrm{n}\end{array}$} \\
\hline & adult female & adult male & immature & & \\
\hline \multicolumn{6}{|l|}{ BFMS } \\
\hline Boabeng & 89 & 38 & 81 & 208 & 13 \\
\hline Fiema & 27 & 16 & 24 & 67 & 6 \\
\hline Total & 116 & 54 & 105 & 275 & 19 \\
\hline \multicolumn{6}{|l|}{ Fragments } \\
\hline Konkrompe & 5 & 9 & 8 & 22 & 2 \\
\hline Bonte & 6 & 8 & 10 & 24 & 2 \\
\hline Bomini & 1 & 2 & 1 & 4 & 1 \\
\hline Busunya & 3 & 10 & 10 & 23 & 3 \\
\hline A. Kuma & 7 & 7 & 3 & 17 & 2 \\
\hline Kwaase & 0 & 0 & 0 & 0 & 0 \\
\hline Tankor & 0 & 0 & 0 & 0 & 0 \\
\hline Senya & 0 & 0 & 0 & 0 & 0 \\
\hline A. Panyin & 0 & 0 & 0 & 0 & 0 \\
\hline Total & 22 & 36 & 32 & 90 & 10 \\
\hline
\end{tabular}

The category 'immature' includes subadults, juveniles and infants.

ables were ranked in order of importance using the model weights and the approach described by Anderson [2008]. All statistical analyses were performed with Statistical Analysis System (SAS) version 9.2. (SAS Institute, Cary, N.C., USA).

\section{Results}

\section{Results of the Census}

The estimated population of C. vellerosus ranged from 4 to 208 individuals in the 7 fragments where they were present (table 1). This translated into a range of population densities between 0.13 ind./ha and 1.63 ind./ha (table 2). Group sizes ranged from 2 to 38 individuals. Four forest fragments had no colobus individuals.

Anecdotal information gathered outside the census period confirmed that some groups move between fragments. In Fiema, three of the groups were non-permanent [C. Serwaa, pers. commun.]. Two groups found most of the year in Boabeng are also known to range in Fiema [R. Koranteng, pers. commun.]. In Bonte, two groups were counted during the census but apparently only one group is present year-round [BoaE. Amponsam, pers. commun.]. Similarly, the group in Bomini is apparently not present year-round in that fragment [N. Gyamfua, pers. commun.].

C. vellerosus Abundance in Relation to Fragment Characteristics

The forest fragments differed in size, isolation from Boabeng, and tree species richness (table 2). Poisson regression models showed that colobus density in fragments

Effect of Forest Fragment Characteristics on Abundance of $C$. vellerosus
Folia Primatol 2013;84:74-86 DOI: $10.1159 / 000348307$ 
Table 2. Description of forest fragments and mean colobus densities

\begin{tabular}{|c|c|c|c|c|c|c|}
\hline Fragment & $\begin{array}{l}\text { Location at centre } \\
\text { of fragment } \\
\text { (latitude, longitude) }\end{array}$ & $\begin{array}{l}\text { Size } \\
\text { ha }^{\text {a }}\end{array}$ & $\begin{array}{l}\text { Distance } \\
\text { from } \\
\text { Boabeng, } \mathrm{m}\end{array}$ & $\begin{array}{l}\text { Vegetation } \\
\text { type }\end{array}$ & $\begin{array}{l}\text { Number of tree } \\
\text { species (species } \\
\text { richness) }\end{array}$ & $\begin{array}{l}\text { Colobus } \\
\text { densities } \\
\text { ind./ha }\end{array}$ \\
\hline Boabeng & $7^{\circ} 42^{\prime} \mathrm{N}, 1^{\circ} 41^{\prime} \mathrm{W}$ & $128.0^{\mathrm{b}, \mathrm{d}}$ & $0^{\mathrm{d}}$ & OF, CF, RF, SW & 135 & 1.63 \\
\hline Fiema & $7^{\circ} 43^{\prime} \mathrm{N}, 1^{\circ} 41^{\prime} \mathrm{W}$ & $62.0^{\mathrm{b}, \mathrm{d}}$ & $20^{\mathrm{d}}$ & OF, SW & 68 & 1.08 \\
\hline Konkrompe & $7^{\circ} 45^{\prime} \mathrm{N}, 1^{\circ} 42^{\prime} \mathrm{W}$ & $38.9^{\mathrm{d}}$ & $3,541^{\mathrm{d}}$ & SW & 60 & 0.56 \\
\hline Bonte & $7^{\circ} 44^{\prime} \mathrm{N}, 1^{\circ} 40^{\prime} \mathrm{W}$ & $33.5^{\mathrm{c}}$ & $1,064^{\mathrm{c}}$ & SW & 44 & 0.72 \\
\hline Bomini & $7^{\circ} 43^{\prime} \mathrm{N}, 1^{\circ} 39^{\prime} \mathrm{W}$ & $30.6^{\mathrm{c}}$ & $1,688^{c}$ & SW & 54 & 0.13 \\
\hline Busunya & $7^{\circ} 41^{\prime} \mathrm{N}, 1^{\circ} 39^{\prime} \mathrm{W}$ & $54.1^{\mathrm{c}}$ & $1,138^{\mathrm{c}}$ & $\mathrm{OF}, \mathrm{RF}$ & 66 & 0.44 \\
\hline A. Kuma & $7^{\circ} 41^{\prime} \mathrm{N}, 1^{\circ} 40^{\prime} \mathrm{W}$ & $34.2^{\mathrm{c}}$ & $294^{\mathrm{c}}$ & $\mathrm{OF}, \mathrm{RF}$ & 76 & 0.50 \\
\hline Kwaase & $7^{\circ} 40^{\prime} \mathrm{N}, 1^{\circ} 38^{\prime} \mathrm{W}$ & $4.9^{\mathrm{d}}$ & $4,667^{\mathrm{d}}$ & $\mathrm{OF}$ & 14 & 0 \\
\hline Tankor & $7^{\circ} 40^{\prime} \mathrm{N}, 1^{\circ} 44^{\prime} \mathrm{W}$ & $6.8^{\mathrm{d}}$ & $3,862^{\mathrm{d}}$ & OF & 35 & 0 \\
\hline Senya & $7^{\circ} 46^{\prime} \mathrm{N}, 1^{\circ} 42^{\prime} \mathrm{W}$ & $74.9^{\mathrm{d}}$ & $5,632^{\mathrm{d}}$ & SW & 43 & 0 \\
\hline A. Panyin & $7^{\circ} 41^{\prime} \mathrm{N}, 1^{\circ} 40^{\prime} \mathrm{W}$ & $3.2^{\mathrm{c}}$ & $677^{c}$ & OF & 19 & 0 \\
\hline \multicolumn{7}{|c|}{$\begin{array}{l}\mathrm{OP}=\text { Open forest; } \mathrm{CF}=\text { closed forest; } \mathrm{RF}=\text { riverine forest; } \mathrm{SW}=\text { savanna-woodland. } \\
\text { a Fragment size includes settlement areas where settlements are found within the fragments. } \\
\mathrm{b} \text { The area designated as the Boabeng Fiema Monkey Sanctuary is approximately } 496 \text { ha, but the core } \\
\text { est is approximately } 190 \text { ha. } \\
{ }^{c} \text { Wong and Sicotte [2006]. }\end{array}$} \\
\hline
\end{tabular}

was influenced by all 3 variables. The best model combined fragment size and isolation distance, with probability or weight of 0.79 in support of this model (model 5; table 3 ). The other 2 models with weights in the $95 \%$ confidence set combined either isolation distance and tree species richness $\left(w_{7}=0.11\right)$ or all 3 variables $\left(w_{8}=0.10\right)$ (table 3$)$. No other models were supported. The ranking of variables based on model weights indicated that the best predictor of population density is fragment size, followed by isolation distance, and then tree species richness (table 4). Quantitatively, isolation distance and fragment size are 4-5 times as important as tree species richness.

The model selection results indicated that the best model is the one that includes fragment size and isolation distance only, with a model probability of 0.79 (table 3 ). To get to at least a $90 \%$ confidence set of models, a model with tree species richness (specifically model 7 , which is the second best with a probability of 0.11 ) should be considered useful. Analysis of parameter estimates of models 5 and 7 reveals that each parameter has the sign in agreement with our a priori hypothesis. Fragment size and tree species richness were positively associated with colobus density, whereas isolation distance was negatively associated with colobus density (table 5).

\section{Discussion}

Our analysis suggests that the order of importance of the variables that predict the colobus densities in this constellation of 11 forest fragments is isolation distance $>$ fragment size $>$ tree species richness (table 4 ). The isolation distance from Boabeng

$\begin{array}{lll}80 & \text { Folia Primatol } 2013 ; 84: 74-86 & \text { Kankam/Sicotte } \\ \text { DOI: } 10.1159 / 000348307 & \end{array}$


Table 3. Model selection results for the probability that colobus density is influenced by the predictors

\begin{tabular}{llllrrr}
\hline Model & Number of variables & log & $\begin{array}{l}\text { Number } \\
\text { of param- } \\
\text { eters }\end{array}$ & & & \\
& & & & & \\
\hline 1 & intercept only & $1,416.0$ & 1 & 690.9 & 419.2 & 0.00 \\
2 & intercept, fragment size & $1,561.6$ & 2 & 402.7 & 130.9 & 0.00 \\
3 & intercept, isolation distance & $1,573.7$ & 2 & 378.6 & 106.8 & 0.00 \\
4 & intercept, tree species richness & $1,592.5$ & 2 & 340.9 & 69.2 & 0.00 \\
5 & intercept, fragment size, isolation distance & $1,629.1$ & 3 & 271.8 & 0.0 & 0.79 \\
6 & intercept, fragment size, tree richness & $1,593.0$ & 3 & 343.9 & 72.1 & 0.00 \\
7 & intercept, isolation distance, tree richness & $1,627.1$ & 3 & 275.7 & 4.0 & 0.11 \\
8 & intercept, fragment size, isolation distance, & $1,629.7$ & 4 & 275.8 & 4.1 & 0.10 \\
& tree richness & & & & & \\
\hline
\end{tabular}

$\mathrm{AICc}=$ Akaike's information criterion corrected for small sample size; $\triangle \mathrm{AICc}=$ difference between a particular model's AICc and the lowest AICc across all candidate models for a species; $w_{i}=$ Akaike weights.

Table 4. Relative importance of variables influencing colobus densities in the forest fragments in BFMS and surrounding communities

\begin{tabular}{lll}
\hline Variable & Sum of probabilities & Rank \\
\hline Isolation distance & 1.00 & 1 \\
Fragment size & 0.89 & 2 \\
Tree species richness & 0.21 & 3 \\
\hline
\end{tabular}

was the most important factor explaining the density of colobus in the fragments in our analysis. The isolation distance from Boabeng, which is the likely source of the colobus population, negatively influenced the presence of colobus densities in the forest fragments. That is, the further away a fragment is from Boabeng, the less likely that colobus would occupy that fragment permanently. However, information gathered outside our census period shows that fragments quite distant from Boabeng (Tankor and Bomini) have had intermittent colobus visits [A. Dassah, Wildlife Officer-in-charge of BFMS, pers. commun.]. Bomini in particular is known to have had intermittent visits by colobus between 2003 and 2007, and had one group during the census, although this group does not occupy the fragment continuously [A. Dassah, pers. commun.]. Between 1993 and 1997, colobus were also spotted in villages farther away from Boabeng (e.g. Nkoranza: 21 km from Boabeng; Asekyere Krokese: $>10 \mathrm{~km}$ from Boabeng) [Kankam, 1997], and recently colobus monkeys have been spotted in farmlands with scattered tall trees close to Senya and Tankor, fragments that had no colobus during the census [A. Dassah, pers. commun.]. Taken together, this informa-

Effect of Forest Fragment Characteristics on Abundance of $C$. vellerosus
Folia Primatol 2013;84:74-86 DOI: $10.1159 / 000348307$ 
Table 5. Maximum likelihood parameter estimates for two Poisson regression models of colobus density

\begin{tabular}{llrlrr}
\hline Model & Parameter & Estimate & $\begin{array}{l}\text { Standard } \\
\text { error }\end{array}$ & $\begin{array}{l}\text { Lower 95\% } \\
\text { CL (Wald) }\end{array}$ & $\begin{array}{r}\text { Upper 95\% } \\
\text { CL (Wald) }\end{array}$ \\
\hline 5 & intercept & 3.6536 & 0.1084 & 3.4411 & 3.8660 \\
& fragment size & 0.0121 & 0.0011 & 0.0099 & 0.0143 \\
& isolation distance & -0.0004 & 0.0000 & -0.0005 & -0.0003 \\
\hline 7 & intercept & 3.2787 & 0.1460 & 2.9926 & 3.5649 \\
& isolation distance & -0.0003 & 0.0000 & -0.0004 & -0.0003 \\
& tree species richness & 0.0142 & 0.0014 & 0.0115 & 0.0168 \\
\hline
\end{tabular}

Density was scaled by a factor of 10 to convert decimal numbers to integers. Confidence limits (CL) are Wald estimates. See table 3 for additional models that were weakly supported or unsupported.

tion suggests that colobus can reach fragments distant from the likely source of the population (Boabeng), but sometimes choose not to stay. This suggests that the distance from Boabeng per se might not be a major factor that limits the dispersal of $C$. vellerosus, but that rather a combination of factors (e.g. fragment size and tree species richness) plays a part in the dispersal of colobus between fragments. A combined effect of isolation distance and habitat quality on the abundance of monkeys, such as the one presumably occurring here, has been reported by Onderdonk and Chapman [2000] for Procolobus (Piliocolobus) pennantii and by Chapman et al. [2003] for Cercopithecus ascanius.

Higher densities of colobus were found in larger forest fragments in this study. This relationship, known as the occupancy-abundance relationship, is well documented (intra- and interspecifically) in a range of taxa, particularly butterflies, fish and birds [Venier and Fahrig, 1998; Gaston et al., 2000; Holt et al., 2002]. The mechanisms underlying this relationship are debated. In this study, the resources available in the fragments, the position of the fragments in relation to others, or elements related to population dynamics (differential fecundity, different vulnerability to predation or hunting) could explain the distribution of individuals in the fragments, keeping in mind that these mechanisms are not mutually exclusive [Gaston et al., 2000]. Repeated measures of colobus densities and habitat quality in this complex of forest fragments over several years would be necessary to help clarify the main mechanism(s) at work.

Habitat quality, and in our case, tree species richness was the weakest predictor among the 3 in terms of probability ranking as a predictor of colobus densities in the fragments; however, the contribution of tree species richness cannot be ignored. Several studies report a positive association between the abundance of monkeys and tree species richness [Medley, 1993; Chapman and Chapman, 1999; Umapathy and Kumar, 2000; Cristóbal-Azkarate et al., 2005]. Generally speaking, however, C. vellerosus was found to be in tree species-rich forest fragments; therefore, availability of potential food trees might be important to colobus. This result is not surprising because 
even though C. vellerosus can live on few plant species in the short term, they might not be able to survive on these diets for long periods in species-poor fragments [Onderdonk and Chapman, 2000; Wong and Sicotte, 2006]. In fact, colobus feed on a large number of different plant species (C. satanas [McKey et al., 1981]; Procolobus badius, P. verus, and C. polykomos [Davies et al., 1999]; C. guereza [Fashing, 2001]; C. vellerosus [Saj and Sicotte, 2007]), and may require forest fragments that are speciesrich. The large trees found in closed forests are also preferred sleeping trees for the colobus [Teichroeb et al., 2012].

The configuration of the forest fragments also parallels the level of protection the colobus receive. Indeed, the populations of colobus in the fragments of Boabeng and Fiema are traditionally protected [Fargey, 1991; Saj et al., 2005] and in recent decades, this protection has expanded to some of the other fragments [Saj et al., 2005]. However, it is likely that the level of protection decreases with the distance from Boabeng. From historical accounts given by local informants, it seems that the fragments outside Boabeng and Fiema did not shelter colobus monkeys before 1983 [Kankam, 1997]. Konkrompe did not shelter colobus before 2000 [A. Dassah, pers. commun.]. The disappearances of colobus in some of the more distant fragments (following their sighting) could potentially be explained by hunting [Saj and Sicotte, 2013] or by further dispersal.

This complex of naturally occurring, anthropogenically influenced forest fragments in central Ghana is thus an important habitat for C. vellerosus, a species that is apparently on the decline in most of its range in the Upper Guinea Forest [Saj and Sicotte, 2013]. As the colobus population in Boabeng and Fiema increases [Wong and Sicotte, 2006; Kankam et al., 2010], some of the unoccupied fragments (or those that receive only intermittent visits) may become more important as potential habitats to dispersing monkeys. Our results suggest that management measures should focus on protecting these small fragments to facilitate colobus movements, as it seems that several groups use more than one fragment, possibly because of intergroup competition or because the food supply or the tree species found in a single fragment may not allow them to meet their nutritional requirements.

\section{Acknowledgments}

We thank the chiefs and elders of all the fragments, the Wildlife Division of Ghana and the Management Committee of the Boabeng Fiema Monkey Sanctuary for granting permission to conduct this research at BFMS. We are grateful to Mr. Anthony Dassah (Senior Wildlife Officer at BFMS) for his support in many ways. Thanks to all the research assistants, especially Robert Koranteng for helping in counting the monkeys and Moses Ampofo (herbalist) and J.Y. Amponsah for assisting in identifying the plants. We thank one anonymous reviewer for comments that helped improve an earlier version of the manuscript. We thank Dr. Tak Fung of University of Calgary, Canada and Dr. Emmanuel Anokye Frimpong Department of Fish and Wildlife Conservation, College of Natural Resources and Environment Virginia Polytechnic Institute and State University, USA, for statistical guidance. This study was supported by the Natural Sciences and Engineering Research Council of Canada (grant held by Dr. Pascale Sicotte), and the University of Calgary, Canada. 


\section{References}

Abu-Juam M, Gyakari JN, Ekpe PK (1996). Boabeng-Fiema Monkey Sanctuary Floral Inventory. Unpublished report prepared for the Boabeng-Fiema Monkey Sanctuary Management Committee.

-Achard F, Eva H, Stibig HJ, Mayaux P, Gallego J, Richards T, Malingreau JP (2002). Determination of deforestation rates of the world's humid tropical forests. Science 297: 999-1002.

Afikorah-Danquah S (1997). Local resource management in the forest-savanna transition zone: the case of Wenchi district, Ghana. Institute of Development Studies Bulletin 28: 36-46.

Allison PA (1962). Historical inferences to be drawn from the human settlement on the vegetation of Africa. The Journal of African History 3: 241-249.

Anderson DR (2008). Model Based Inference in the Life Sciences: A Primer on Evidence. New York, Springer.

Anderson J, Cowlishaw G, Rowcliffe JM (2007). Effects of forest fragmentation on the abundance of Colobus angolensis palliates in Kenya's Coastal forests. International Journal of Primatology 28: 637655 .

-Arroyo-Rodríguez V, Dias PAD (2010). Effects of habitat fragmentation and disturbance on howler monkeys: a review. American Journal of Primatology 72: 1-16.

-Arroyo-Rodríguez V, Mandujano S, Benitez-Malvido J (2008). Landscape attribute affecting patch occupancy by howler monkeys (Alouatta pallita mexicana) at Los Tuxtlas, Mexico. American Journal of Primatology 70: 69-77.

Asare EO (1962). A note on the vegetation of the transition zone of the Tain Basin in Ghana. Ghana Journal of Science 2: 60-373.

Baker LR, Tanimola AA, Olubode OS, Garshelis DL (2009). Distribution and abundance of sacred monkeys in Igboland, southern Nigeria. American Journal of Primatology 71: 574-586.

Barbour MG, Burk JH, Pitts WD, Schwartz MW (1999). Terrestrial Plant Ecology, 3rd ed. Menlo Park, Addison Wesley Longman Inc.

Baytas A, Rezvani F (2000). Forest Resource Accounting in Ghana, 1970-1987. Centre for Economic Research on Africa. New Jersey, Montclair State University.

- Beier P, Van Drielen M, Kankam BO (2002). Avifaunal collapse in West African forest fragments. Conservation Biology 16: 1097-1111.

Booth CP (1956). The colobus monkeys of Ghana. African Wildlife 12: 313-318.

Boyle SA, Smith AT (2010). Can landscape and species characteristics predict primate presence in forest fragments in the Brazilian Amazon? Biological Conservation 143: 1134-1143.

Chapman CA, Chapman LJ (1999). Implications of small-scale variation in ecological conditions for the diet and density of red colobus monkeys. Primates 40: 215-231.

Chapman CA, Lawes MJ, Naughton-Treves L, Gillespie T (2003). Primate survival in community-owned forest fragments: are metapopulation models useful amidst intensive use? In Primates in Fragments: Ecology in Conservation (Marsh LK, ed.), pp 63-78. New York, Kluwer Academic/Plenum.

Condit R, Foster RB, Hubbell SP, Sukumar R, Leigh EG, Manokaran N, Loo de Lao S, LaFrankie JV, Ashton PS (1998). Assessing forest diversity on small plots: calibration using species-individual curves from 50 ha plots. In Forest Biodiversity Diversity Research, Monitoring, and Modeling (Dallmeier F, Comiskey JA, eds.). Paris, The Parthenon Publishing Group.

Cristóbal-Azkarate J, Veà JJ, Asensio N, Rodrıguez-Luna E (2005). Biogeographical and floristic predictors of the presence and abundance of mantled howler monkeys (Alouatta palliata mexicana) in rain forest fragments at Los Tuxtlas, Mexico. American Journal of Primatology 67: 209-222.

Davies AG, Oates JF, Dasilva GL (1999). Patterns of frugivory in three West African colobine monkeys. International Journal of Primatology 20: 327-357.

Dudley N, Phillips A (2006). Forests and Protected Areas: Guidance on the Use of the IUCN Protected Area Management Categories. Gland, IUCN.

Fargey PJ (1991). Assessment of the Conservation Status of the Boabeng-Fiema Monkey Sanctuary. Final report to the Flora and Fauna Preservation Society, University of Science and Technology, Kumasi, Ghana.

Fashing PJ (2001). Feeding ecology of guerezas in the Kakamega forest, Kenya: the importance of Moraceae fruit in their diet. International Journal of Primatology 22: 579-609.

Gaston KJ, Blackburn TM, Greenwood JJD, Gregory RD, Quinn RM, Lawton JH (2000). Abundanceoccupancy relationships. Journal of Applied Ecology 37: 39-59.

Groves C (2001). Primate Taxonomy. Washington, Smithsonian Institution Press.

Hall JB, Swaine MD (1981). Distribution and Ecology of Vascular Plants in a Tropical Rain Forest: Forest Vegetation in Ghana. The Hague, Dr W Junk Publishers.

Hawthorne WD, Gyakari N (2006). Photoguide for the Forest Trees of Ghana: Tree-Spotter's Field Guide for Identifying the Largest Trees. Oxford, Oxford Forestry Institute. 
Hawthorne WD, Jongkind CCH (2006). Woody Plants of Western Africa: A Guide to the Forest Trees, Shrubs and Lianes from Senegal to Ghana. Kew, Kew Publishing, Royal Botanic Gardens.

Hopkins B (1974). Forest and Savanna, 2nd ed. London, Heinemann Education Books.

Holt RL, Gaston KJ, Fangliang H (2002). Occupancy-abundance relationships and spatial distribution: a review. Basic and Applied Ecology 3: 1-13.

International Union for Conservation of Nature (IUCN) (1996). The Conservation Atlas of Tropical Forests: the Americas, vol. 3 (Harcourt CS, Sayer J, Billington C, eds.). New York, Simon and Schuster.

International Union for Conservation of Nature (IUCN) (2010). IUCN Red List of Threatened Species. Gland, IUCN. www.iucnredlist.org.

Jarman P, Smith AP, Southwell C (1996). Complete counts. In Measuring and Monitoring Biological Diversity (Wilson DE, Cole FR, Nicols JD, Rudran R, Foster MS, eds.), pp 192-193. London, Smithsonian Institution Press.

Jeffrey SM (1975). Notes on mammals from the high forest of western Ghana (excluding Insectivora). Bulletin de l'Institut Fondamental d'Afrique Noire 37: 950-972.

Kankam BO (1997). The Population of Black-and-White Colobus (Colobus polykomos) and the Mona Monkeys (Cercopithecus mona) at the Boabeng-Fiema Monkey Sanctuary and Surrounding Villages. BSc Thesis, University of Science and Technology, Kumasi, Ghana.

Kankam BO, Saj T, Sicotte P (2010). How to measure 'success' in community-based conservation projects: the case of the Boabeng-Fiema Monkey Sanctuary in Ghana. In The Public Sphere and the Politics of Survival in Ghana (Puplampu KP, Tettey WJ, eds.), pp 115-141. Accra, Woeli Publishing Services.

Kufeld RC, Bowden DC, Schrupp DL (1988). Influence of hunting on movements of female mule deer. Journal of Wildlife Management 41: 70-72.

Laurance WF (1994). Rainforest fragmentation and the structure of small mammal communities in tropical Queensland. Biological Conservation 69: 23-32.

Mbora DNM, Meikle DB (2004). Forest fragmentation and the distribution, abundance and conservation of the Tana river red colobus (Procolobus rufomitratus). Biological Conservation 118: 67-77.

McKey DB, Gartlan JS, Waterman PG, Choo GM (1981). Food selection by black colobus monkeys (Colobus satanas) in relation to plant chemistry. Biological Journal of the Linnean Society 16: 115-146.

Medley KE (1993). Primate conservation along the Tana river, Kenya: an examination of the forest habitat. Conservation Biology 7: 109-121.

Migeod FWH (1914). The Gold Coast: its physical features, flora, fauna, and ethnology. Journal of the Royal African Society 13: 369-384.

Mitsch WJ, Gosselink JG (2000). Wetlands, 3rd ed. New York, Van Nostrand Reinhold.

Onderdonk DA, Chapman CA (2000). Coping with forest fragmentation: the primates of Kibale National Park, Uganda. International Journal of Primatology 21: 587-611.

Rodriguez-Toledo EM, Mandujano S, Garcia-Orduna F (2003). Relationships between forest fragments and howlers (Alouatta palliata mexicana) in southern Veracruz, Mexico. In Primates in Fragments: Ecology in Conservation (Marsh LK, ed.), pp 79-97. New York, Kluwer Academic/Plenum Publishers.

Ross C, Reeve N (2003). Survey and census methods: population distribution and density. In Field and Laboratory Methods in Primatology (Setchell JM, Curtis DJ, eds.), pp 90-109. Cambridge, Cambridge University Press.

Saj TL, Sicotte P (2007). Predicting the competitive regime of female Colobus vellerosus from the distribution of food resources. International Journal of Primatology 28: 315-336.

Saj TL, Sicotte P (2013). Species profile for Colobus vellerosus. In Mammals of Africa, vol 2, (Butynski TM, Kingdon J, Kalina J, eds.) pp 109-111. London, Bloomsbury.

Saj T, Teichroeb JA, Sicotte P (2005). The population status and habitat quality of the ursine colobus (Colobus vellerosus) at Boabeng-Fiema, Ghana. In Commensalism and Conflict: The Human-Primate Interface (Paterson JD, Wallis J, eds.), pp 350-375. Norman, American Primatological Society Publishing.

Salzmann U (2000). Are modern savannas degraded forests? - A Holocene pollen record from the Sudanian vegetation zone of NE Nigeria. Vegetation History and Archaeobotany 9: 1-15.

Scott CT (1998). Sampling methods for estimating change in forest resources. Ecological Applications 8: 228-233.

Swaine MD, Hall JB, Lock JM (1976). The forest-savanna boundary in west-central Ghana. Ghana Journal Sciences 16: 35-52.

Swaine MD (1992). Characteristics of dry forest in West Africa and the influence of fire. Journal of Vegetation Science 3: 365-374.

Teichroeb JA, Holmes TD, Sicotte P (2012). Use of sleeping trees by ursine colobus monkeys (Colobus vellerosus) demonstrates the importance of nearby food. Primates 53: 287-296.

Teichroeb JA, Wikberg CA, Sicotte P (2011). Dispersal in male ursine colobus monkeys (Colobus vellerosus): influence of age, rank and contact with other groups on dispersal decisions. Behaviour 148: 765-793.

Effect of Forest Fragment Characteristics on

Folia Primatol 2013;84:74-86 
Turner IM, Corlett RT (1996). The conservation value of small, isolated fragments of lowland tropical rain forest. Trends in Ecology and Evolution 11: 330-333.

- Umapathy G, Kumar A (2000). The occurrence of arboreal mammals in the rain forest fragments in the Anamalai Hills, South India. Biological Conservation 92: 311-319.

Venier LA, Fahrig L (1998). Intra-specific abundance-distribution relationships. Oikos 82: 483-490.

-Wong SNP, Saj TL, Sicotte P (2006). Comparison of habitat quality and diet of Colobus vellerosus in forest fragments in Ghana. Primates 47: 365-373.

Wong SNP, Sicotte P (2006). Population size and density of Colobus vellerosus at the Boabeng-Fiema Monkey Sanctuary and surrounding forest fragments in Ghana. American Journal of Primatology 68: $465-476$. 